\title{
Functional Integration of Embryonic Stem Cell-Derived Neurons In Vivo
}

\author{
Marius Wernig, ${ }^{1}$ Felix Benninger, ${ }^{2}$ Tanja Schmandt, ${ }^{1}$ Monika Rade, ${ }^{1}$ Kerry L. Tucker, ${ }^{4}$ Heinrich Büssow, ${ }^{3}$ Heinz Beck, ${ }^{2}$ \\ and Oliver Brüstle ${ }^{1}$ \\ ${ }^{1}$ Institute of Reconstructive Neurobiology, University of Bonn Medical Center and Hertie Foundation, Departments of ${ }^{2}$ Epileptology and ${ }^{3}$ Anatomy, \\ University of Bonn, D-53105 Bonn, Germany, and ${ }^{4}$ Interdisciplinary Center for Neurosciences, University of Heidelberg, D-69120 Heidelberg, Germany
}

Pluripotency and the potential for continuous self-renewal make embryonic stem (ES) cells an attractive donor source for neuronal cell replacement. Despite recent encouraging results in this field, little is known about the functional integration of transplanted ES cellderived neurons on the single-cell level. To address this issue, ES cell-derived neural precursors exhibiting neuron-specific enhanced green fluorescent protein (EGFP) expression were introduced into the developing brain. Donor cells implanted into the cerebral ventricles of embryonic rats migrated as single cells into a variety of brain regions, where they acquired complex morphologies and adopted excitatory and inhibitory neurotransmitter phenotypes. Synaptic integration was suggested by the expression of PSD-95 (postsynaptic density-95) on donor cell dendrites, which in turn were approached by multiple synaptophysin-positive host axon terminals. Ultrastructural and electrophysiological data confirmed the formation of synapses between host and donor cells. Ten to $21 \mathrm{~d}$ after birth, all EGFP-positive donor cells examined displayed active membrane properties and received glutamatergic and GABAergic synaptic input from host neurons. These data demonstrate that, at the single-cell level, grafted ES cell-derived neurons undergo morphological and functional integration into the host brain circuitry. Antibodies to the region-specific transcription factors Bf1, Dlx, En1, and Pax6 were used to explore whether functional donor cell integration depends on the acquisition of a regional phenotype. Our data show that incorporated neurons frequently exhibit a lacking or ectopic expression of these transcription factors. Thus, the lack of an appropriate regional "code" does not preclude morphological and synaptic integration of ES cell-derived neurons.

Key words: embryonic stem cells; neural precursors; electrophysiology; transplantation; tau; gene targeting

\section{Introduction}

Transplantation of neural precursors has developed into a key strategy for cell replacement in the CNS (Rossi and Cattaneo, 2002). A major limitation of this approach is the availability of donor tissue. Studies involving clinical neurotransplantation have, so far, relied primarily on fetal brain tissue (Bjorklund and Lindvall, 2000; Freed et al., 2001; Lindvall, 2001). Approaches to bypass the shortage in donor tissue include expansion of neural stem cells in vitro by mitogen treatment (Reynolds and Weiss, 1992; Gage et al., 1995; Johe et al., 1996; Studer et al., 1998; Ostenfeld et al., 2000), the ex vivo introduction of growthstimulating oncogenes (Shihabuddin et al., 1995; Snyder et al., 1995; Lundberg et al., 1997; Barresi et al., 2003), xenotransplantation (Fink et al., 2000), enhancement of endogenous adult neurogenesis (Kuhn et al., 1997; Magavi et al., 2000; Nakatomi et al., 2002), and attempts to recruit non-neural adult stem cells from

Received Aug. 11, 2003; revised April 21, 2004; accepted April 24, 2004.

This work was supported by the Hertie Foundation, Deutsche Forschungsgemeinschaft (TR-SFB 3), and Helga Ravenstein-Stiftung. We thank Alberto Perez-Bouza and Karen Tolksdorf for helpful advice in electron microscopy. M. Watanabe, G. Panganiban, and L. Studer generously provided the PSD-95, DII, and Bf- 1 antibodies, respectively. We gratefully acknowledge Rachel Buschwald, Anke Leinhaas, Michaela Segschneider, and Michaela Lindemann for technical support.

Correspondence should be addressed to Dr. Oliver Brüstle, Institute of Reconstructive Neurobiology, University of Bonn Medical Center, Sigmund-Freud-Strasse 25, D-53105 Bonn, Germany. E-mail: brustle@uni-bonn.de. DOI:10.1523/JNEUROSCI.0428-04.200

Copyright $\odot 2004$ Society for Neuroscience $\quad$ 0270-6474/04/245258-11\$15.00/0 other tissues (Brazelton et al., 2000; Mezey et al., 2000, 2003; Jiang et al., 2002).

Recent advances in embryonic stem (ES) cell technology have opened an alternative, fascinating perspective to generate neural donor cells in unlimited quantities. Protocols have been established for the efficient generation of pan-neural, glial, and neuronal-restricted precursors from ES cells (Okabe et al., 1996; Li et al., 1998; Brüstle et al., 1999; Mujtaba et al., 1999). After transplantation, ES cell-derived neural precursors incorporate into the CNS and differentiate into neurons and glia (Brüstle et al., 1997; McDonald et al., 1999; Liu et al., 2000; Reubinoff et al., 2001; Zhang et al., 2001).

Despite the broad experimental application of neuronal transplantation, few studies have addressed the functional integration of single neurons in the host CNS. The availability of transfectable fluorescent labels such as the enhanced green fluorescent protein (EGFP) has greatly facilitated electrophysiological recordings from living donor cells. The results of recent studies indicate that grafted fetal neural precursors and immortalized cell lines develop functional properties of postmitotic neurons (Auerbach et al., 2000; Englund et al., 2002). Functional studies on ES cell-derived neurons have, so far, focused primarily on cell culture experiments. In vitro, ES cell-derived neurons exhibit voltage-gated inward and outward currents, express functional neurotransmitter receptors, and form synaptic contacts (Bain et al., 1995; Strübing et al., 1995, 1997; Finley et al., 1996). A recent 
publication suggests that dopaminergic progenitors generated from ES cells in vitro and grafted into the striatum of 6-OHDAlesioned rats give rise to localized clusters of dopaminergic neurons, which display electrophysiological properties similar to endogenous cells (Kim et al., 2002).

In this study, we demonstrate on the single-cell level that ES cell-derived neurons have the potential to functionally integrate into a large variety of brain regions. Yet, many of the incorporating donor neurons fail to express region-specific genes. Only a fraction of them adopt a regionally appropriate transcription factor expression, indicating that functional integration overrides positional identity.

\section{Materials and Methods}

ES cell differentiation. Tau::EGFP knock-in ES cells were generated by targeting the cDNA for EGFP in frame into exon 1 of the Tau gene, resulting in a fusion protein that consists of the first 31 amino acids of Tau and EGFP (Tucker et al., 2001). Because of the absence of microtubule-binding domains at the carboxyl terminus, the fluorescence signal is distributed throughout the cytoplasm. In vitro differentiation of ES cells was performed as described previously (Okabe et al., 1996). Briefly, ES cells were expanded on $\gamma$-irradiated mouse embryonic fibroblasts in DMEM (Invitrogen, Karlsruhe, Germany) supplemented with $20 \%$ fetal bovine serum (AG seromed; Biochrom, Berlin, Germany), $1 \times$ MEM-nonessential amino acids (Invitrogen), $8 \mathrm{mg} / \mathrm{l}$ adenosine, $8.5 \mathrm{mg} / \mathrm{l}$ guanosine, $7.3 \mathrm{mg} / \mathrm{l}$ cytidine, $7.3 \mathrm{mg} / \mathrm{l}$ uridine, $2.4 \mathrm{mg} / \mathrm{l}$ thymidine, $0.1 \mathrm{~mm}$ 2-mercaptoethanol, $26 \mathrm{~mm}$ HEPES (all from Sigma, Taufkirchen, Germany), and $10^{3} \mathrm{U} / \mathrm{ml}$ leukemia inhibitory factor (LIF) (Chemicon, Hofheim, Germany). After passaging onto gelatin-coated dishes $(0.1 \%$ gelatin; Sigma), ES cells were trypsinized and transferred to bacterial dishes allowing embryoid body (EB) formation. EBs were propagated for $4 \mathrm{~d}$ in the absence of LIF and subsequently plated onto tissue culture dishes. One day after plating, the medium was replaced by ITSFn [i.e., DMEM/F12 (Invitrogen) supplemented with $5 \mu \mathrm{g} / \mathrm{ml}$ insulin, $50 \mu \mathrm{g} / \mathrm{ml}$ human APO-transferrin (both from Intergene, Purchase, NY), 30 nm sodium selenite (Sigma), 2.5 $\mu \mathrm{g} / \mathrm{ml}$ fibronectin (Invitrogen), and penicillin/streptomycin (Invitrogen). After 5-7 d, cells were trypsinized, triturated to a single-cell suspension, and resuspended in HBSS for transplantation.

Gene expression analysis. Total RNA was extracted from 5- to 7-d-old ITSFn cultures (representing primarily neural precursor cells) (Okabe et al., 1996) using Trizol (Invitrogen) following the instructions of the manufacturer. Reverse transcribed cDNA (Superscript II; Invitrogen) was amplified with PCR using primers specific for Bf1 (F-ggg caa caa cca ctc ctt ctc cac, R-gac ccc tga ttt tga tgt gtg aaa, 395 bp), Pax6 (F-agt cac agc gga gtg aat cag c, R-agc cag gtt gcg aag aac tct g, 383 and 425 bp), En1 (F-tgg tca aga ctg act cac agc a, R-tct cgt ctt tgt cct gaa ccg t, 389 bp), Dlxl (F-tac atc agt tcc gtg cag tcc tac, R-ttc cca gat gag gag ttc gga ttc, $403 \mathrm{bp}$ ), and $\beta$-actin (F-cgt ggg ccg ccc tag gca cca, R-ctt agg gt cag ggg ggc, 238 bp). All primer pairs were exon spanning except for Bf1. In this case, a PCR without the reverse transcription step was performed to exclude contaminating genomic DNA.

Cell transplantation, tissue analysis, and quantification. Surgery was performed as described previously (Brüstle et al., 1996). In brief, embryonic day (E) 16.5 timed pregnant Sprague Dawley rats (Charles River, Sulzfeld, Germany) were anesthetized with ketamine- $\mathrm{HCl}$ and xylazine ( 80 and $10 \mathrm{mg} / \mathrm{kg}$ body weight, i.p., respectively). The uterine horns were exposed, and the telencephalic vesicles of the embryos were identified under transillumination. Using a glass capillary, $2-4 \times 10^{5}$ cells in a volume of 4-8 $\mu$ l of HBSS were injected into one telencephalic vesicle. Injected embryos were placed back into the abdominal cavity for spontaneous delivery. One or $14 \mathrm{~d}$ after birth, animals were perfused transcardially with $4 \%$ paraformaldehyde. The brains were removed and cut on a vibratome into $50 \mu \mathrm{m}$ coronal sections or cryoprotected in $15 \%$ saccharose, frozen in isopentan, and sectioned into $50 \mu \mathrm{m}$ slices. In some animals, obstruction of the ventricular system resulted in severe hydrocephalus. These animals were excluded from additional analysis. Mouse monoclonal antibodies were used to detect $\beta$-III tubulin (1:500; Babco, Richmond, CA), neuronal-specific nuclear protein (1:200; Chemicon),
$\mathrm{GABA}_{\mathrm{A}}$ receptors ( $\beta$-chain, clone BD17; 1:50; Chemicon), synaptophysin (1:40), pan-cytokeratin (clone Lu-5; 1:50; both from DAKO, Hamburg, Germany), Pax6, En1, and Nestin (1:10, 1:10, and 1:50, respectively; Developmental Studies Hybridoma Bank, Iowa City, IA), and calbindin (1:5.000; Swant, Bellinzona, Switzerland). Primary rabbit antibodies were directed against Bf1 (a generous gift from Dr. L. Studer, Memorial Sloan-Kettering Cancer Center, New York, NY), GAD-65/67 (1:2.000; Chemicon), tyrosin hydroxylase (1:200; Affinity Research Products, Mamhead, UK), serotonin (1:2.000; Biogenesis, Poole, UK), the AMPA receptor subunit glutamate receptor 1 (GluR1; 1:300; Sigma), the NMDA receptor subunit NR1 (1:1.000; Chemicon), and PSD-95 (postsynaptic densitity protein; a generous gift from Dr. M. Watanabe, Hokkaido University, Sapporo, Japan) (Fukaya and Watanabe, 2000). Dlx proteins were detected by using an antibody raised against the Drosophila Dll protein that binds to all vertebrate Dlx homologs (a generous gift from Dr. G. Panganiban, University of Wisconsin, Madison, WI) (Panganiban et al., 1995). A polyclonal goat antibody was used to detect the excitatory amino-acid carrier 1 (EAAC1), a neuronal glutamate transporter protein (1:8000; Chemicon). Primary antibodies were applied overnight in $1 \%$ normal goat or donkey serum in PBS. Antigens were visualized using appropriate rhodamine- or cyanin 3-conjugated secondary antibodies (Jackson ImmunoResearch, West Grove, PA). Sections were preserved in Vectashield (Vector Laboratories, Burlingame, CA) and observed on Zeiss (Oberkochen, Germany) Axioskop 2, Zeiss LSM510, and Leica (Nussloch, Germany) True Confocal Scanner laser scan microscopes. The number of incorporated cells was determined in a minimum of three $50 \mu \mathrm{m}$ thick sections per animal and brain region. Incorporated neurons were defined as EGFP-positive cells located at least $50 \mu \mathrm{m}$ from the ventricular wall or a cluster of transplanted cells. In situ hybridization using a mouse-specific DNA probe was performed as described previously (Brüstle et al., 1995). Alkaline phosphatase activity was detected histochemically (alkaline phosphatase detection kit; Vector Laboratories).

Electron microscopy. For preembedding immunohistochemistry, 50 $\mu \mathrm{m}$ vibratome sections were incubated with a polyclonal antibody to EGFP (1:4.000; Abcam, Cambridge, UK), followed by a peroxidaselabeled secondary antibody (Jackson ImmunoResearch) and staining with diaminobenzidine precipitate (DAKO). Stained sections were postfixed overnight in $2.5 \%$ glutaraldehyde, photodocumented, dehydrated in graded ethanol series, and embedded in Epon (Epoxy-Embedding kit; Fluka, Buchs, Switzerland) between two plastic slides overnight at $60^{\circ} \mathrm{C}$. Regions of interest were microdissected into small fragments $(\sim 1.5 \times 3$ $\mathrm{mm})$ and fixed onto an Epon block with a drop of liquid Epon after incubation at $60^{\circ} \mathrm{C}$ for $>12 \mathrm{hr}$. Ultrathin sections were prepared on a Leica Ultracut Microtome, stained with uranyl acetate and lead citrate (10 min each), and observed on a Zeiss EM 900 electron microscope.

Slice preparation and electrophysiology. For electrophysiological recordings, recipient animals were decapitated under deep ether anesthesia, and $300 \mu \mathrm{m}$ horizontal sections were prepared using a vibratome (Leica VT1000S). Slices were transferred to the stage of an upright microscope (Zeiss Axioskop FS II) and perfused with artificial CSF containing (in mM): $125 \mathrm{NaCl}, 3 \mathrm{KCl}, 1.25 \mathrm{NaH}_{2} \mathrm{PO}_{4}, 25 \mathrm{NaHCO}_{3}, 2.0 \mathrm{CaCl}_{2}, 1.0$ $\mathrm{MgCl}_{2}$, and 20 glucose, $\mathrm{pH} 7.3(\mathrm{NaOH})$, for current-clamp recordings as well as recordings of voltage-dependent membrane currents. For recordings of NMDA receptor-mediated EPSCs, glycine $(5 \mu \mathrm{M})$ was added to the extracellular solution. In addition, $\mathrm{MgCl}_{2}$ was omitted from the extracellular solution in some experiments. The blockers of synaptic transmission 6-cyano-7-nitroquinoxaline-2,3-dione disodium salt (CNQX; $50 \mu \mathrm{M})$, bicuculline $(10 \mu \mathrm{M})$, and $\mathrm{D}(-)$-2-amino-5-phosphonopentanoic acid (AP-5; $50 \mu \mathrm{M})$ were bath-applied.

EGFP-positive cells were readily identified using a fluorescence camera (Spot Jr.; Diagnostic Instruments, Puchheim, Germany) (see Fig. $3 A_{2}$ ), and these cells were subsequently visualized using infrared video microscopy and differential interference contrast optics to obtain patchclamp recordings under visual control (see Fig. $3 A_{1}$ ). For each recording, positive identification of the EGFP-positive donor cell was confirmed by diffusion of EGFP into the patch pipette (see Fig. $3 A_{3}$ ). Cells were recorded from the following incorporation sites: neocortex $(n=15)$, hippocampus $(n=12)$, inferior colliculus $(n=11)$, thalamus $(n=8)$, striatum $(n=7)$, superior colliculus $(n=6)$, amygdala $(n=6)$, septum $(n=4)$, hypothala- 
mus $(n=4)$. For five cells, the incorporation site could not be attributed to a defined region.

Glass microelectrodes were pulled from borosilicate glass ( $2.0 \mathrm{~mm}$ diameter; wall thickness, $420 \mu \mathrm{m})$ and had a resistance of 3.0-4.5 $\mathrm{M} \Omega$. For current-clamp recordings, pipettes contained (in $\mathrm{mM}$ ): $20 \mathrm{KCl}, 120$ potassium gluconate, 10 EGTA, 10 HEPES, $2 \mathrm{MgCl}_{2}, 2$ ATP. For recordings of postsynaptic currents (PSCs), pipettes contained (in $\mathrm{mm}$ ): 110 cesium methanesulfonate, 2 $\mathrm{MgCl}_{2}, 10$ 1,2-bis(2-amino-5-bromophenoxy) ethane- $N, N, N^{\prime}, N^{\prime}$-tetraacetic acid, 2 ATP, 10 HEPES, 20 tetraethylammonium chloride, 5 $N$-ethyl bromide quaternary salt, $\mathrm{pH} 7.4(\mathrm{NaOH})$. Liquid junction potentials were not compensated. All chemicals were purchased from Sigma.

Whole-cell voltage- and current-clamp recordings were obtained at room temperature using a patch-clamp amplifier (EPC9; Heka Elektronik, Lambrecht/Pfalz, Germany). After establishing the whole-cell configuration, the resting membrane potential and cell capacitance were measured. In all voltage-clamp recordings, the capacitance compensation circuitry of the patch-clamp amplifier was used to reduce capacitive transients. Series resistance was on average $16.3 \pm 1.8$ and was compensated by $>70 \%$. Traces were leak-subtracted on-line. PSCs were elicited by a $0.1 \mathrm{msec}$ current pulse delivered via a monopolar glass stimulation electrode. For eliciting PSCs, stimulation electrodes were placed at a distance between 360 and $820 \mu \mathrm{m}$ from the recorded cell. The vicinity of the stimulation electrode was carefully examined for the presence of EGFP-positive profiles, and only stimulation sites devoid of such profiles were used.

Data analysis. The time constants of PSC decay $(\tau)$ were determined by fitting a single exponential equation of the following form to the falling phase of the PSCs: $I(t)=A_{0}+A_{1} \cdot[1-$ $\exp (-t / \tau)]$, where $I(t)$ is the current amplitude at the time point $t$, and $A_{0}$ is a constant offset. Fitting and determination of $10-90 \%$ rise times of PSCs were performed using the program Igor (WaveMetrix, Lake Oswego, OR). Spike threshold was defined as the membrane potential where the slope of the voltage trace increased abruptly during membrane charging induced by positive current pulses. Spike amplitude was measured as the voltage difference between the peak of the action potential and resting membrane potential $\left(\mathrm{V}_{\mathrm{m}}\right)$. Spike width was calculated as spike duration at $50 \%$ of the spike amplitude.

\section{Results}

Grafted ES cell-derived neural precursors exhibit widespread migration and differentiation into multiple neuronal phenotypes

The neuron-specific EGFP fluorescence in progeny of tau::EGFP mutant ES cells provides a reliable system for the detection and live analysis of transplanted ES cell-derived neurons on the cellular level (Tucker et al., 2001; Wernig et al., 2002). To study their potential for functional integration, we grafted ES cell-derived neural precursors into the ventricle of E16.5 rat embryos. The donor cells were prepared according to a well established in vitro
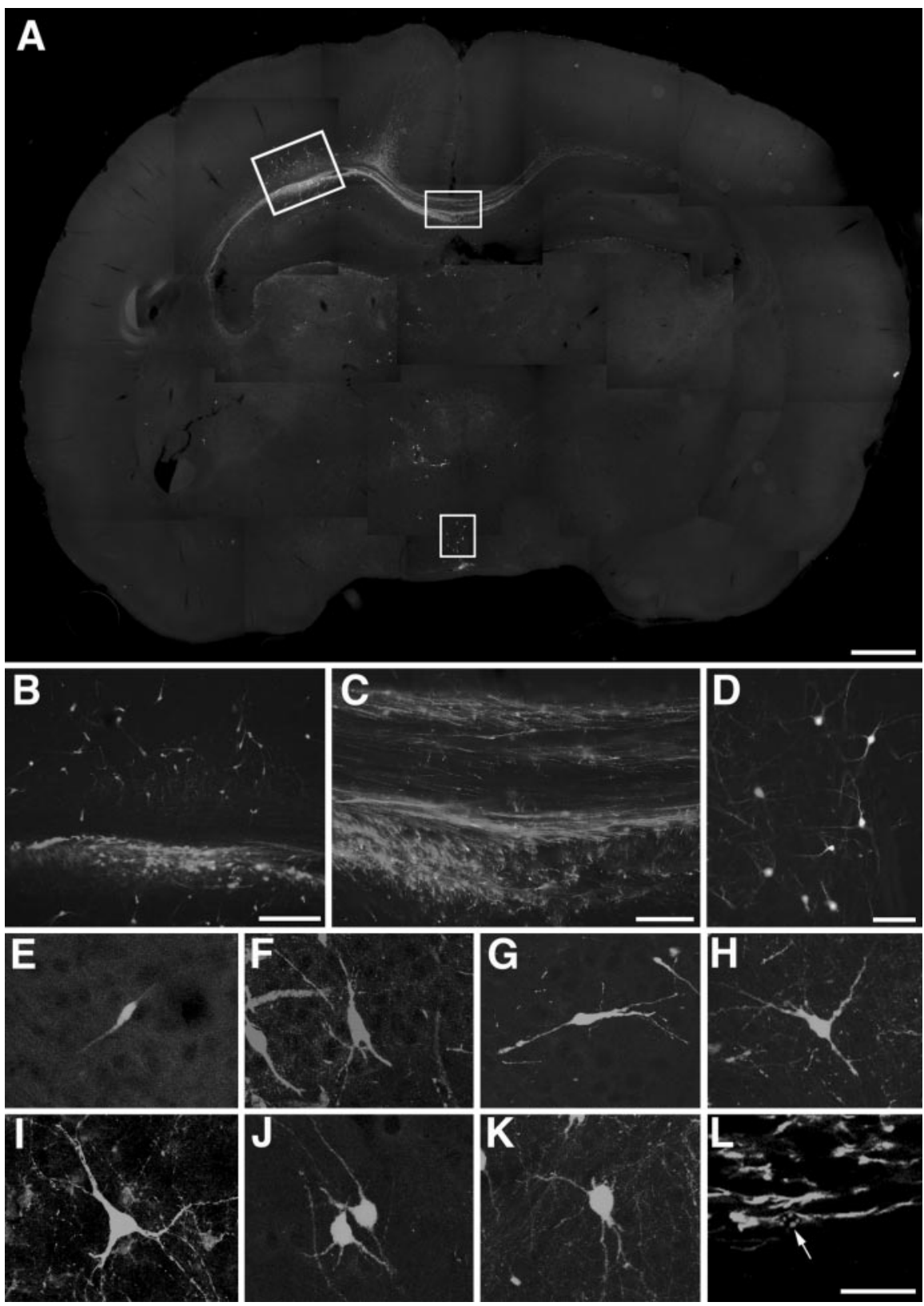

Figure 1. Incorporation of ES cell-derived neurons into the developing rat brain. $A-K$, Engrafted donor cells identified by virtue of their EGFP fluorescence $(E, G-K)$ or immunofluorescence with an antibody to EGFP $(A-D, F)$ generate a variety of neuronal phenotypes. $A$, Twenty days after transplantation into the ventricle of $\mathrm{E} 16.5$ rats, the cells formed intraventricular clusters and migrated as single cells into various host brain regions. $B-D$, Higher power microphotographs of areas indicated in $A$, depicting incorporation into neocortex $(B)$ and hypothalamus $(D)$. Donor-derived cortical neurons were found to extend long axons into the corpus callosum (C).E-K, Confocal microscopy and digital reconstruction revealed that the transplanted cells adopt a variety of morphologies, including simple bipolar cells resembling young migratory neurons ( $E$, neocortex), complex phenotypes mimicking principal pyramidal neurons of the hippocampus ( $F$, $C A 1$ pyramidal cell layer), and multipolar cell types ( $G, H$, neocortex; I, septum; $J$, thalamus; $K$, tectum). L, Immunofluorescence analysis with an antibody to nestin depicts engrafted cells with immature, elongated phenotypes characteristic of migratory precursor cells. The arrow points to the mouse-specific DNA in situ hybridization signal used for donor cell identification (tectum, confocal analysis). Scale bars: $A, 1 \mathrm{~mm} ; B, 200 \mu \mathrm{m} ; C, D, 100 \mu \mathrm{m} ; E-L, 50 \mu \mathrm{m}$.

differentiation protocol, which yields highly enriched neural progenitor cells with only minor fractions of postmitotic neurons and non-neural cell types (Okabe et al., 1996; Wernig et al., 2002). The intrauterine transplantation method results in widespread incorporation of the donor cells into the ventricular zone, from where they migrate into a variety of host brain regions, thus generating neural chimeras (Brüstle et al., 1995, 1998; Campbell et al., 1995; Fishell, 1995). Similar to the results of these previous 
Table 1. Incorporation of ES cell-derived neurons into the developing rat brain

\begin{tabular}{|c|c|c|c|c|c|c|c|c|c|c|c|c|}
\hline$\overline{\text { Animal }}$ & $O B$ & NCX & HPC & $C C$ & AMG & SPT & STR & $\mathrm{TH}$ & HT & MB & $C B$ & $\mathrm{PO}$ \\
\hline P1 & & $<1$ & & & & & & & $<1$ & $16 \pm 4$ & & \\
\hline P1 & & & & & & & & & $29 \pm 5$ & $48 \pm 5$ & & \\
\hline P1 & & $18 \pm 2$ & & $10 \pm 1$ & & & & & $9 \pm 2$ & $35 \pm 10$ & & \\
\hline P1 & $7 \pm 4$ & $<1$ & & $<1$ & & $9 \pm 2$ & & $<1$ & $22 \pm 2$ & $72 \pm 7$ & $8 \pm 2$ & \\
\hline P14 & & $21 \pm 4$ & $21 \pm 3$ & & $15 \pm 1$ & & & & $<1$ & & & \\
\hline P14 & & & $22 \pm 5$ & & $37 \pm 11$ & & & & & $54 \pm 23$ & & \\
\hline P14 & & & & & & $<1$ & & $112 \pm 40$ & $66 \pm 11$ & $72 \pm 18$ & & \\
\hline P14 & & $54 \pm 5$ & $37 \pm 6$ & $23 \pm 6$ & & & $30 \pm 5$ & & & $23 \pm 7$ & & \\
\hline P14 & & $16 \pm 4$ & & $<1$ & $26 \pm 8$ & & $17 \pm 2$ & $14 \pm 6$ & $23 \pm 8$ & & & \\
\hline P14 & & $20 \pm 4$ & $52 \pm 22$ & & & $25 \pm 14$ & & $15 \pm 8$ & $12 \pm 3$ & $86 \pm 18$ & & \\
\hline P14 & & & $34 \pm 11$ & & $117 \pm 22$ & & & & $30 \pm 9$ & $63 \pm 9$ & $2 \pm 1$ & \\
\hline P14 & $65 \pm 11$ & $10 \pm 1$ & $25 \pm 8$ & $37 \pm 10$ & $67 \pm 21$ & & & $<1$ & & $45 \pm 13$ & & \\
\hline P14 & & $47 \pm 6$ & $31 \pm 6$ & $6 \pm 1$ & & $27 \pm 15$ & $27 \pm 7$ & $56 \pm 12$ & $44 \pm 12$ & $165 \pm 11$ & $<1$ & $43 \pm 15$ \\
\hline P14 & & $<1$ & $59 \pm 12$ & $31 \pm 5$ & $86 \pm 15$ & $40 \pm 8$ & $24 \pm 4$ & $31 \pm 11$ & $52 \pm 12$ & $53 \pm 5$ & & $<1$ \\
\hline P14 & $24 \pm 5$ & $85 \pm 24$ & $9 \pm 3$ & $28 \pm 9$ & & $59 \pm 16$ & $41 \pm 9$ & $29 \pm 8$ & $68 \pm 10$ & $106 \pm 14$ & $5 \pm 2$ & $22 \pm 5$ \\
\hline P14 & & $53 \pm 32$ & $10 \pm 4$ & $19 \pm 3$ & $52 \pm 12$ & $31 \pm 8$ & $22 \pm 7$ & $36 \pm 7$ & $39 \pm 7$ & $24 \pm 8$ & $3 \pm 1$ & $15 \pm 5$ \\
\hline P14 & $20 \pm 3$ & $20 \pm 4$ & $49 \pm 5$ & $55 \pm 14$ & $46 \pm 7$ & $52 \pm 39$ & $10 \pm 3$ & $48 \pm 10$ & $65 \pm 14$ & $122 \pm 14$ & & $52 \pm 10$ \\
\hline P14 & $93 \pm 8$ & $40 \pm 11$ & $30 \pm 6$ & $24 \pm 9$ & $136 \pm 33$ & $59 \pm 16$ & $23 \pm 7$ & $58 \pm 13$ & $60 \pm 14$ & $66 \pm 7$ & $<1$ & $71 \pm 24$ \\
\hline
\end{tabular}

The distribution of the engrafted neurons showed pronounced inter-individual and intra-individual variations. Numbers indicate the mean and SD of incorporated EGFP-positive cells per region and $50 \mu \mathrm{m}$ section. A minimum of three sections per region and animal was analyzed. OB, Olfactory bulb; NCX, neocortex; HPC, hippocampus; CC, corpus callosum; AMG, amygdala; SPT, septum; STR, striatum; TH, thalamus; HT, hypothalamus; MB, midbrain; $C B$, cerebellum; P0, pons.

studies, neural precursors derived from heterozygous tau::EGFP knock-in ES cells formed intraventricular clusters and migrated as single cells to a large number of brain regions (Fig. 1, Table 1). Donor cell clusters within the ventricular system showed large variations with respect to size and content of EGFP-positive cells. In addition to small, mostly EGFP-positive clusters (Fig. 1A,B), larger, tumorous formations with the histological appearance of teratomas had developed in most animals. One to 3 weeks after transplantation, graft-derived neurons had incorporated as single cells into the gray and white matter of telencephalon, diencephalon, metencephalon, and mesencephalon. Brain regions exhibiting efficient donor cell incorporation included neocortex, hippocampus, amygdala, thalamus, hypothalamus, and midbrain (Fig. 1A, B,D-G,J-K; Table 1). Engraftment into the midbrain area was particularly efficient, reaching donor cell densities of up to 219 cells per $50 \mu \mathrm{m}$ section (see Table 1). ES cell-derived neurons also incorporated into olfactory bulb, septum (Fig. 1I), stri-
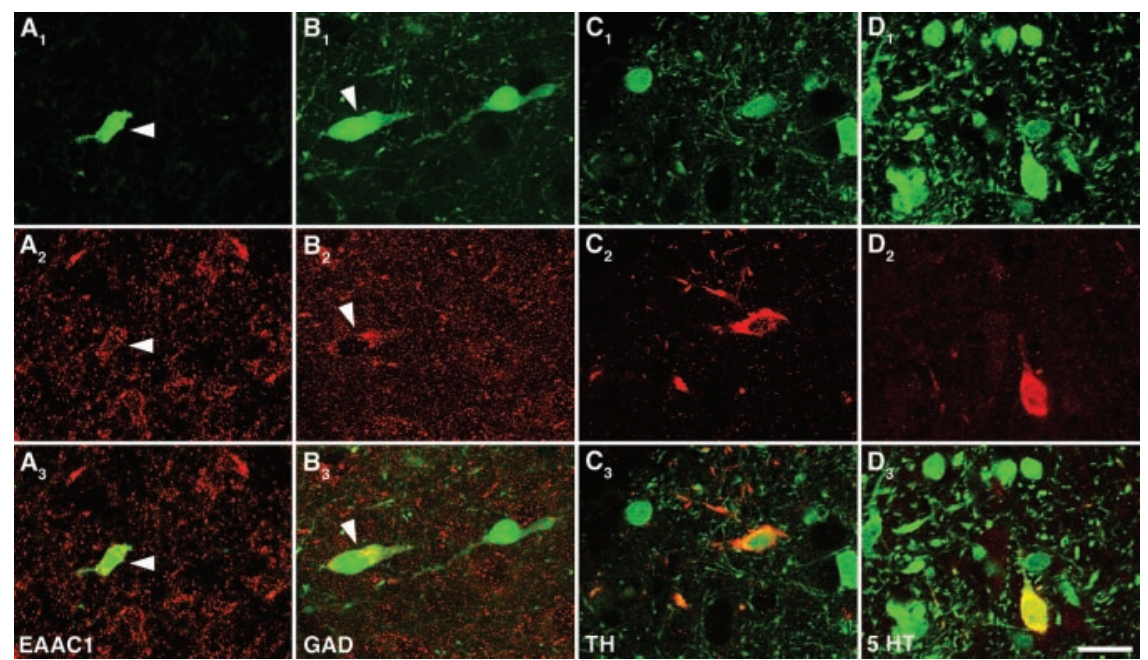

Figure 2. Integrated ES cell-derived neurons differentiate into various neurotransmitter subtypes. $A, B$, Confocal microscopy demonstrated that many EGFP-positiveneurons were double labeled with antibodies to EAAC1, suggesting a glutamatergic phenotype $(A$, cortex) and GAD-65/67, the rate-limiting enzyme for GABA synthesis $(B)$. Arrowheads indicate double-labled cells. A smaller fraction of EGFPpositive cells expressed tyrosin hydroxylase (TH; C, thalamus) or serotonin (5-HT; D, thalamus). Scale bar, $20 \mu \mathrm{m}$. atum, corpus callosum, and pons, although with less efficiency. Only occasional EGFP-positive neurons were found in cerebellum and medulla oblongata. Generally, the donor cell density decreased with increasing distance from the ventricular wall, enabling the study of individual donor neurons incorporated as isolated cells into areas remote from the ventricular system (Fig. $1 A$ ). Because of large variations in size and shape of the intraventricular clusters, no detailed quantification of their cell content was performed. However, we estimate that not $>10 \%$ of the grafted cells left the ventricles and migrated into the brain parenchyma. As in previous studies (Brüstle et al., 1995), we found that donor cells originating from the aqueduct migrate preferentially in a dorsal direction, invading the tectum. In the rostral telencephalon, transplanted neurons frequently entered the rostral migratory stream and the granular cell layer of the olfactory bulb (equivalent to Brüstle et al., 1997).

The strong EGFP fluorescence provided a crisp outline of the incorporated cells, clearly delineating their neuronal processes

(Fig. $1 E-K$ ). EGFP-positive cells exhibited various neuronal morphologies ranging from simple bipolar cells resembling young migratory neurons (Fig. 1E) to more complex phenotypes mimicking principal pyramidal neurons in the hippocampus (Fig. $1 F$ ) and multipolar neuronal cell types (Fig. $1 G-$ $K)$. The presence of immature neural cells alongside differentiated neurons was further supported by donor-specific DNA in situ hybridization and double labeling with an antibody to nestin (Fig. $1 L$ ). These studies revealed donor cells with hybridized nuclei and nestin-positive elongated processes characteristic of migrating neural cells (Fig. $1 L$ ).

Immunofluorescence analysis revealed that the engrafted donor cells had differentiated into various neurotransmitter subtypes (Fig. 2). Overall, $44.7 \pm 11.4 \%$ of the incorporated EGFP-positive cells expressed the neuronal glutamate transporter protein EAAC1, suggesting efficient 
differentiation into glutamatergic neurons ( $n=1775$ cells analyzed in 10 recipients) (Fig. $2 A_{1-3}$ ). A smaller population of $14.6 \pm 10.1 \%$ expressed GAD-65/67, the rate-limiting enzyme for GABA synthesis indicating a GABAergic phenotype $(n=$ 2237 cells analyzed in 9 recipients) (Fig. $\left.2 B_{1-3}\right)$. Some EGFP fluorescent cells were double labeled with antibodies to tyrosine hydroxylase $(5.3 \pm 8.2 \% ; n=2399$ cells analyzed in 9 brains), a marker for catecholaminergic neurons (Fig. $2 C_{1-3}$ ). Only occasionally, EGFP-positive donor cells were found double labeled with antibodies to serotonin (Fig. 2 $D_{1-3}$ ). Donor neurons incorporated into various host brain regions showed no striking differences in the distribution of excitatory and inhibitory neurotransmitter phenotypes (Table 2).

The tau::EGFP transgene did not permit the visualization of glial donor cells. However, considering the results of previous studies (Brüstle et al., 1997), it appears likely that the transplanted ES cell-derived neural precursors also gave rise to astrocytes and oligodendrocytes, an issue not further explored in this study. Despite the presence of intraventricular teratomas, the brain parenchyma did not appear to be disrupted by invading masses of non-neural tissue. However, infiltration of individual cells of non-neural origin could not be excluded solely on the basis of light microscopy. Additional alkaline phosphatase histochemistry was used to exclude the presence of undifferentiated ES cells within the host tissue. The absence of invading nonneural epithelial cells was confirmed with an antibody to cytokeratin, which, at the same time, labeled donor cells within the teratoma-like formations (data not shown). Based on these analyses, we found no evidence for brain infiltration by non-neural donor cells.

\section{Incorporated ES cell-derived neurons exhibit passive and active membrane properties}

To study the functional membrane properties of the engrafted neurons, acute slices were prepared from transplanted brains at postnatal day (P) 10 to $\mathrm{P} 21$. Fluorescence microscopy permitted unequivocal identification of the incorporated EGFP-positive neurons. Patch-clamp recordings from donor cells $(n=78)$ were obtained under visual control using infrared differential interference contrast optics. In each recording, diffusion of EGFP into the patch pipette after establishing the whole-cell configuration was used to confirm the donor cell identity (Fig. $3 A_{1-3}$ ). The resting membrane potential of ES cell-derived neurons ranged from -48 to $-64 \mathrm{mV}$ (average, $-55.2 \pm 2.6 \mathrm{mV}$ ) with an input resistance of $205 \pm 41 \mathrm{M} \Omega(n=21)$. Recordings in the currentclamp configuration allowed us to determine the active membrane characteristics of EGFP-positive cells. Prolonged (Fig. 3B $B_{1}$ ) and brief (Fig. $3 B_{2}$ ) current injections demonstrated the capability to fire fast action potentials and action potential series (action potential amplitude ranging from 45 to $85 \mathrm{mV}$; average, $66.7 \pm$ $4.9 \mathrm{mV}$; action potential half width ranging from 1.3 to $3.4 \mathrm{msec}$; average, $1.9 \pm 0.2 ; n=19)$. The transplanted neurons also exhibited voltage-dependent membrane currents. Depolarizing voltage steps elicited both large outward currents with a sustained $\mathrm{K}^{+}$ component $(5.4 \pm 1.5 \mathrm{nA})$ and fast inward $\mathrm{Na}^{+}$currents $(4.4 \pm$ $1.0 \mathrm{nA}$ ) (Fig. 3C). Individual recipients were analyzed at later time points. These preliminary data indicate that incorporated neurons can maintain functional activity for up to at least 9 weeks after transplantation. Together, our data demonstrate that ES cell-derived neurons exhibit typical neuronal membrane properties when transplanted into the rodent brain.

\section{Synaptic integration of engrafted ES cell-derived neurons}

To address the question whether the transplanted neurons receive synaptic contacts from host axons, we first examined the expression of the postsynaptic density protein PSD-95. Confocal immunofluorescence analysis revealed a highly localized, punctate pattern within the gray matter as expected (Fukaya and Watanabe, 2000). In EGFP-expressing cells, PSD-95-positive puncta were typically found in close proximity to the cell surface, demonstrating that this major component of the postsynaptic density is expressed and correctly localized to the cell membrane (Fig. $4 A$ ). Next, we visualized presynaptic terminals with an antibody to synaptophysin. Numerous synaptophysin-positive, EGFPnegative patches were found in close apposition to the somatic and dendritic membranes of transplanted cells, suggesting that host-derived presynaptic terminals contact incorporated ES cellderived neurons (Fig. 4B). Ultrastructural analysis was used to confirm synapse formation between host and donor neurons on the morphological level. After pre-embedding immunohistochemistry with an antibody to EGFP, transplanted neurons were clearly detectable in the electron microscope. Careful examination of the donor cell membranes revealed postsynaptic densities in juxtaposition to EGFP-negative, host-derived terminals containing synaptic vesicles (Fig. 4C). 

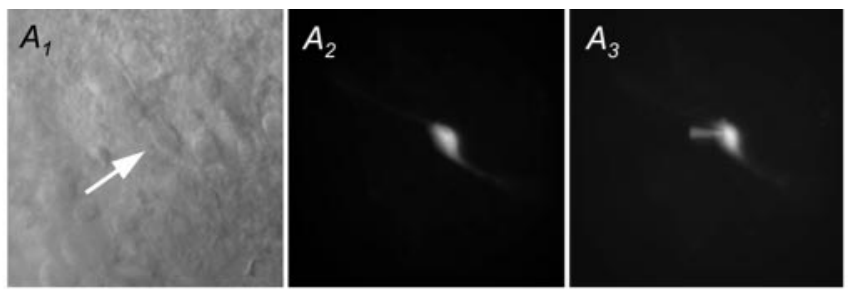

$B_{1}$

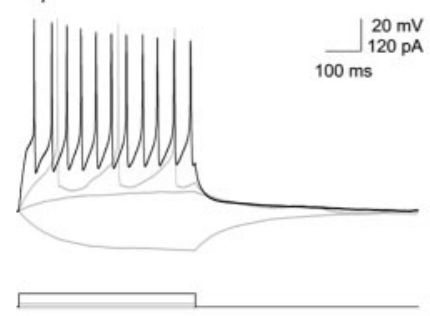

$B_{2}$
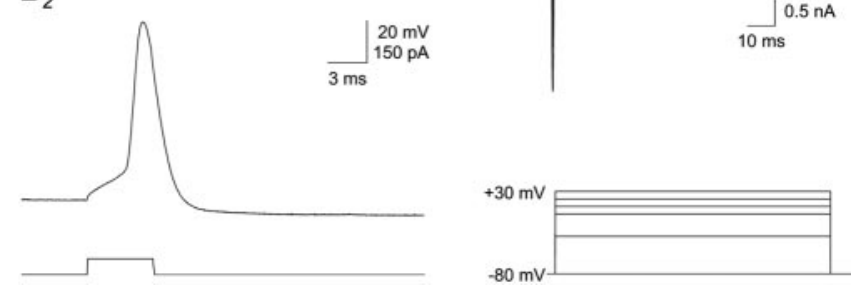

Figure 3. Intrinsic discharge properties and voltage-gated membrane currents observed in engrafted ES cell-derived neurons $20 \mathrm{~d}$ after intrauterine transplantation. $A$, Infrared differential interference contrast image $\left(A_{1}\right)$ and fluorescent image $\left(A_{2}\right)$ of an EGFP-positive donor neuron (arrow) after formation of a gigaseal. In all recordings, diffusion of EGFP into the pipette served as confirmation of the donor cell identity $\left(A_{3}\right)$. $B$, Current-clamp recordings during prolonged $\left(B_{1}\right)$ and brief $\left(B_{2}\right)$ current injections. Top traces represent voltage recordings, whereas bottom traces indicate current injections. To facilitate discrimination of voltage traces, part of the traces and their corresponding current injection steps are shown in gray. C, Voltagedependent membrane currents. Depolarizing voltage steps (bottom traces, potentials as indicated) elicited outward currents with a sustained $\mathrm{K}^{+}$component and fast inward $\mathrm{Na}{ }^{+}$ currents.

We then tested whether incorporated EGFP-positive cells express ionotropic glutamate and GABA receptors using antibodies to the GluR1 AMPA receptor subunit (Fig. $4 D_{1-2}$ ), the $\mathrm{GABA}_{\mathrm{A}}$ receptor $\beta$ chain (Fig. $4 E_{1-2}$ ), and the NR1 subunit of the NMDA receptor (Fig. $4 F_{1-2}$ ). All subunits were clearly present in the majority of incorporated EGFP-positive cells, indicating that ES cell-derived neurons express both glutamatergic and GABAergic neurotransmitter receptors.

Finally, we sought to confirm functional synaptic integration of ES cell-derived neurons into the host brain. To this end, we elicited postsynaptic currents by stimulation with a monopolar stimulation electrode, which was placed 360-820 $\mu \mathrm{m}$ from the recorded cell. The vicinity of the stimulation electrode was carefully examined for the presence of EGFP-positive axonal or dendritic profiles to avoid stimulation of donor-derived neurons. When $\mathrm{GABA}_{\mathrm{A}}$ and NMDA receptors were blocked by bicuculline $(10 \mu \mathrm{M})$ and AP-5 $(50 \mu \mathrm{M})$, respectively, fast EPSCs were readily elicited. These EPSCs were completely abolished after additional application of $50 \mu \mathrm{M} C N Q X$, indicating that they were mediated by AMPA receptors (Fig. $5 A_{1}$, compare left and right panels) $(n=$ $15)$. To estimate the reversal potential, the cell membrane was clamped at potentials ranging from -80 to $+60 \mathrm{mV}$ (Fig. $5 A_{2}$ ) $(n=4)$. The reversal potential was close to $0 \mathrm{mV}$ (Fig. $5 A_{3}$ ). $\mathrm{GABA}_{\mathrm{A}}$ receptor-mediated IPSCs were isolated pharmacologically by applying CNQX and AP-5 (both $50 \mu \mathrm{M}$ ) (Fig. $5 B_{1}$, left panel). The resulting IPSCs were completely blocked after additional application of $10 \mu \mathrm{M}$ bicuculline (Fig. $5 B_{1}$, right panel) $(n=11)$. The reversal potential of GABAergic IPSCs was approximately $-40 \mathrm{mV}$ (Fig. $\left.5 B_{2}, B_{3}\right)(n=5)$. Despite the abundant expression of NR1 within donor neurons, we were unable to detect EPSCs mediated by NMDA receptors ( $n=15$ cells). Together, these morphological and electrophysiological data demonstrate that engrafted ES cell-derived neurons undergo functional synaptic integration into the host brain and receive both AMPA and GABA receptor-mediated input.

\section{Ectopic expression of region-specific markers in transplanted cells}

We next wondered whether and to what extent synaptic integration depends on region-specific differentiation of the donor neurons. Within neocortex and the CA1 pyramidal cell layer of the hippocampus, we detected EGFP-positive cells with pyramidal morphologies, appropriate dendritic orientation, and expression of the neuronal glutamate transporter protein EAAC1, indicating elaboration of local excitatory phenotypes (Figs. $1 F, 6 A$ ). Other donor neurons incorporated into the cortex displayed multipolar or tangential dendrites and expressed calbindin (i.e., features characteristic of cortical interneurons) (Figs. 1G,H, 6B). Although observations such as these might suggest region-specific differentiation, the large variability in donor and host cell phenotypes does not permit any conclusive statements. In fact, we also observed donor cell morphologies without obvious similarities to adjacent host neurons.

To more comprehensively characterize the positional identities of the transplanted neurons, we evaluated the expression of the transcription factor genes $D l x, B f 1, E n 1$, and Pax6. During early development, $D l x$ genes are exclusively expressed in the ventral telencephalon and diencephalon, including the ganglionic eminences, ventral thalamus, and central and lateral areas of the hypothalamus (Price et al., 1991; Liu et al., 1997). Expression of the winged helix transcription factor $B f 1$ is restricted to progenitors that give rise to the telencephalon and is reported to be sustained in the adult forebrain (Tao and Lai, 1992; Hatini et al., 1994; Na et al., 1998). Within the CNS, the En1 gene is expressed in cells of the midbrain-hindbrain junction of midgestation embryos and in a subset of ventral neural tube cells (Davis and Joyner, 1988). Endogenous expression of all three genes was verified by immunofluorescence in the $\mathrm{P} 14$ rat brain, the time point of analysis (Fig. 6). Pax6 transcripts are detectable in the ventral part of the caudal neural tube, in diencephalon, metencephalon, and myelencephalon, and in the lateral and dorsal parts of the telencephalon. Pax6 is absent in the telencephalic ganglionic eminences and in the mesencephalic tectum (Walther and Gruss, 1991). Except for the metencephalic expression domain, which is first observed at day 15.5 postcoitum, this spatial expression pattern is maintained during brain development from E8.0 to E18.5. In contrast to the other genes studied, overall Pax 6 transcription gradually declines after midgestation and becomes confined to discreet cerebral nuclei postnatally (Walther and Gruss, 1991; Stoykova and Gruss, 1994).

Reverse transcriptase PCR analysis showed that all four of these region-specific transcripts are detectable in cultured ES cellderived neural precursors in vitro, indicating that the donor cells can, in principle, express region-specific transcription factors of various brain regions (Fig. 6I). We then used immunofluorescence analyses to study the expression of $D l x, E n 1, B f 1$, and Pax6 in EGFP-positive ES cell-derived neurons engrafted into the olfactory bulb, cortex, striatum, diencephalon, and midbrain. For 
the detection of Dlx, we used an antibody to the Drosophila Dll protein, which binds to all vertebrate Dlx-homologs (Panganiban et al., 1995). Remarkably, only a small fraction of the incorporated cells was found to exhibit a regionally appropriate Dlx expression pattern (Fig. 6C,D; Table 2 ). In striatum, a region within the expression domain of $D l x$, only 11 of 163 cells showed immunoreactivity for Dll $(n=2$ animals) (Fig. 6C). Conversely, donorderived neurons incorporated in areas devoid of $D l x$ frequently exhibited ectopic expression of this marker. In tectum, a region lacking $D l x$ expression, $37 \%$ of the EGFP-fluorescent cells were immunoreactive for Dll ( $n=7$ animals) (Fig. 6D). Similarly, En1, a protein typically expressed in the midbrain region, was detected in neurons engrafted into telencephalon and diencephalon (Table 2). In the olfactory bulb, a structure devoid of endogenous En1 proteins, 107 of 850 cells were immunopositive ( $n=7$ animals) (Fig. $6 E)$. In contrast, only 97 of 2333 transplanted neurons incorporated to the midbrain exhibited En1 expression ( $n=8$ animals) (Fig. 6F). Only a small number of integrated donor neurons acquired a Bf1positive phenotype. Bf1-immunoreactive cells were found in both homotopic and heterotopic sites without an obvious regional preference (Fig. 6G,H; Table 2). Ectopic expression was also detected for Pax6. Five and $11 \%$ of the donor-derived neurons in the Pax6-negative territories striatum and tectum showed nuclear immunoreactivity, respectively $(n=2$ and 7 animals). In neocortex and hippocampus, only $2 \%$ of the donor neurons expressed Pax6 (based on 321 cells analyzed in four animals). Similarly, in diencephalon, only 23 of 884 cells ( $n=4$ animals) were found to be Pax6 positive. The latter findings have to be interpreted with care because Pax6 is known to be downregulated in most postmitotic neurons. Strikingly, the majority of the donor cells engrafted into cortex were negative for all four transcription factors analyzed (Table 2).

\section{Discussion}

\section{Synaptic integration of transplanted ES} cell-derived neurons

Here, we demonstrate on a single-cell level that engrafted ES cell-derived neurons are capable of synaptically integrating into the host brain circuitry. After transplantation into embryonic rat brains, ES cell-derived neural precursor cells efficiently migrate into multiple regions where they differentiate into cells exhibiting morphological and electrophysiological properties of neurons. Furthermore, the incorporated donor neurons receive both excitatory and inhibitory synaptic input from host axons.

ES cells have emerged as an attractive donor source for cell C, $0.4 \mu \mathrm{m}$.
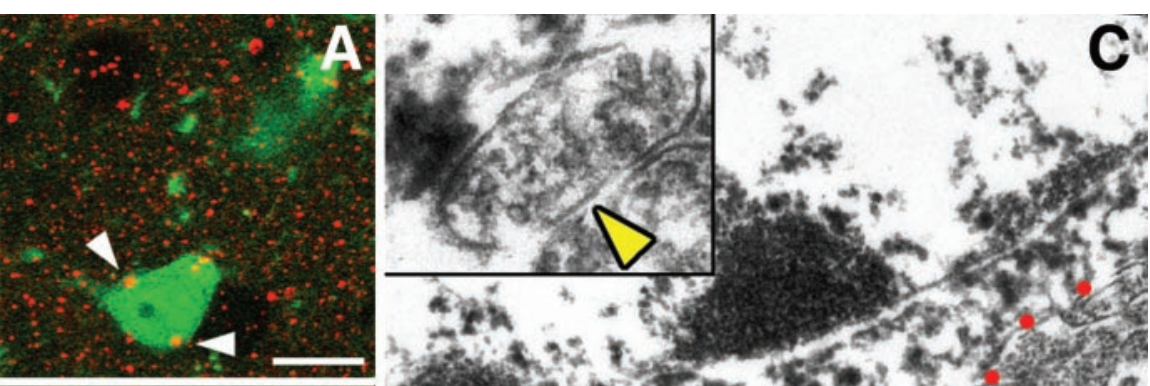

B.
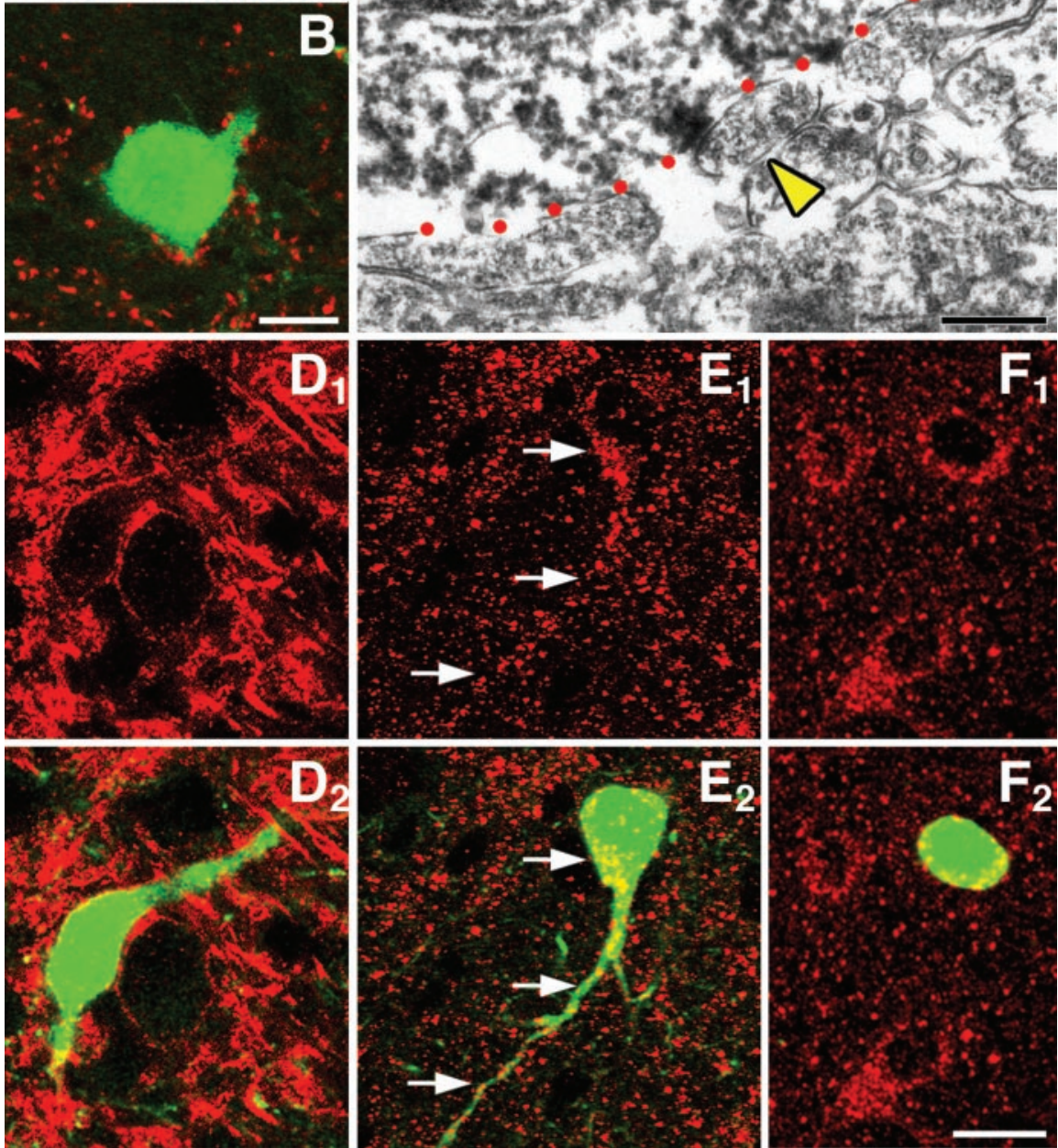

Figure 4. Engrafted ES cell-derived neurons exhibit morphological and immunohistochemical evidence of synapse formation. A, PSD-95-immunoreactive puncta on the cell membrane of an EGFP-fluorescent cell (arrowheads). B, Synaptophysin-positive presynaptic terminals contacting soma and dendrites of an incorporated ES cell-derived neuron. C, Electron micrograph revealing synapse formation between an EGFP-negative terminal containing presynaptic vesicles (yellow arrowhead) and the soma of an EGFP-immunoreactive ES cell-derived neuron (red dotted line marks the border of the EGFP-immunoreactive donor cell). Inset, Higher magnification micrograph from C. D-F, Engrafted neurons express receptors for excitatory and inhibitory neurotransmitters, including the $\mathrm{GABA}_{\mathrm{A}}$ receptor $\beta$-chain ( $D$, tectum), the GluR1 subunit of the AMPA receptor ( $E$, hypothalamus), and the NR1 subunit of the NMDA receptor ( $F$, tectum). $A, B$, and $D-F$ represent single $1.2 \mu \mathrm{m}$ confocal planes. Scale bars: $A, B, D-F, 10 \mu \mathrm{m}$;

replacement strategies (Svendsen and Smith, 1999). However, it is not known whether neurons derived by in vitro differentiation of ES cells exhibit functional properties in vivo. Observations by Kim et al. (2002) indicate that ES cell-derived neurons are capable of projecting onto host neurons after transplantation into an animal model of Parkinson's disease. Although no direct connections between donor and host cells were detected in paired recordings, extracellular stimulation within the striatal grafts resulted in EPSPs in endogenous stellate neurons. In addition, extracellular stimulation was found to elicit IPSPs in donor neu- 
A

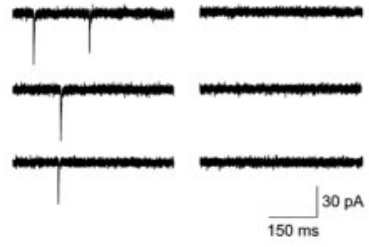

$B_{1}$

$A_{2}$

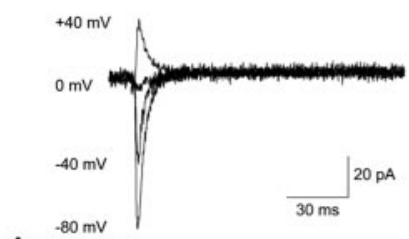

$A_{3}$

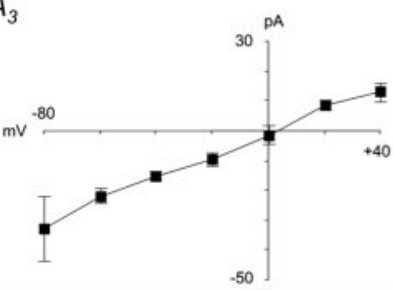

$B_{3}$

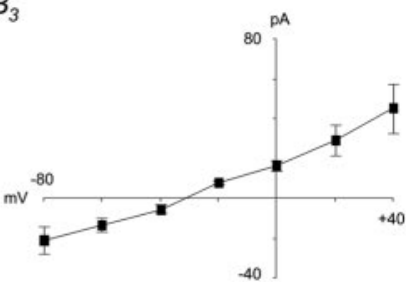

Figure 5. Excitatory and inhibitory synaptic transmission from host to $\mathrm{ES}$ cell-derived neurons. $A$, AMPA receptor-mediated EPSCs. Extracellular stimulation of host neurons readily evoked fast EPSCs in the presence of bicuculline (10 $\mu \mathrm{M})$ and AP-5 (50 $\mu \mathrm{M})$ ( $A_{1}$, leftmost traces). EPSCs were completely abolished after additional application of the AMPA receptor blocker CNQX $(50 \mu \mathrm{m})\left(A_{1}\right.$, rightmost traces). To estimate the reversal potential, the cell membrane was clamped at different voltages ( -80 to $+40 \mathrm{mV}$ as indicated), and AMPA receptor-mediated EPSCS were elicited by synaptic stimulation. The reversal potential was close to $0 \mathrm{mV}\left(A_{2}, A_{3}\right) . B$, $G A B A_{A}$ receptor-mediated synaptic input. Slow IPSCs were elicited after stimulation in the presence of $50 \mu \mathrm{M}$ CNQX and AP-5 ( $B_{1}$, leftmost traces). These currents were completely abolished after additional application of $10 \mu \mathrm{m}$ bicucilline ( $B_{1}$, rightmost traces). Analogous to $A$, the cell membrane was clamped at different potentials as indicated, and $G A B A_{A}$ receptor-mediated IPSCS were elicited by stimulation with a monopolar stimulation electrode. The reversal potential was approximately $-40 \mathrm{mV}\left(B_{2}, B_{3}\right)$.

rons, suggesting synaptic input onto the transplanted cells. The interpretations of these observations are complicated by the lack of an intravital label, precluding the identification of donorderived processes and a clear distinction between endogenous and grafted cells during the electrophysiological assessment.

In the current study, this critical point is bypassed using ES cells engineered to express EGFP in a neuron-specific manner, permitting the prospective identification of engrafted donorderived neurons and their processes (Tucker et al., 2001; Wernig et al., 2002). To study individual donor neurons in various host brain regions, we abandoned classic intraparenchymal injection and implanted the cells into the ventricle of embryonic recipients. Typically, cells grafted in this manner enter the ventricular zone and migrate as single cells into a large variety of brain regions (Brüstle et al., 1995; Campbell et al., 1995; Fishell, 1995).

After transplantation, the grafted ES cell-derived precursors formed prominent intraventricular clusters. From there, neural donor cells migrated into the host brain parenchyma. Frequently, the intraventricular clusters also contained non-neural tissues. These teratoma-like structures most likely originated from residual undifferentiated ES cells in the grafted cell suspension. Incorporated donor neurons exhibited a broad spectrum of neuronal morphologies ranging from simple bipolar to complex multipolar phenotypes. Most cells differentiated into glutamatergic and GABAergic, some into catecholaminergic, and only a small num- ber into serotoninergic subtypes. Electrophysiological assessment demonstrated that all incorporated neurons analyzed displayed active membrane properties. Donor neurons expressed proteins essential for synaptic transmission, including the postsynaptic density protein and the major subunits of ionotropic glutamate and GABA receptors (NR1, GluR1, and $\mathrm{GABA}_{\mathrm{A}}$ receptor $\beta$-chain, respectively). Synaptophysin-reactive dots were found surrounding somata and dendrites of transplanted neurons, suggesting the presence of presynaptic terminals adjacent to their membranes. Synapse formation between host and donor neurons was confirmed by ultrastructural and functional studies. Extracellular stimulation of host neurons and patchclamp recordings from incorporated donor neurons yielded both AMPA and $\mathrm{GABA}_{\mathrm{A}}$ receptor-mediated postsynaptic currents in the engrafted cells. In contrast, we found no evidence for EPSCs mediated by NMDA receptors. Yet, many donor neurons were decorated with an antibody against the NR1 subunit of the NMDA receptor. The reasons for this striking discrepancy remain unclear, but a similar scarceness of NMDA receptormediated responses has been observed in cell culture experiments (Finley et al., 1996) and in previous studies on the functional integration of ES cell-derived neurons in cultured hippocampal slices (Benninger et al., 2003).

The transplanted cells not only gave rise to neurons incorporating into the host brain but also formed large intraventricular clusters containing, in addition to EGFP-positive cells, primitive neuroepithelial structures and areas of non-neural differentiation. These and previous findings (Brüstle et al., 1997) indicate that ES cell-derived neural precursors derived from plated embryoid bodies cultured in ITSFn medium (Okabe et al., 1996) still contain a fraction of undifferentiated cells capable of teratoma formation. Although additional propagation in defined growth factor-containing media and lineage selection strategies can be used to enrich neural cells and eliminate undifferentiated cells ( $\mathrm{Li}$ et al., 1998; Brüstle et al., 1999; Mujtaba et al., 1999; Carpenter et al., 2003), we decided to use immature, highly migratory cell populations at an early stage of differentiation for this study.

\section{Region-specific differentiation is no prerequisite for functional integration}

A number of studies have focused on the regional plasticity of neural precursors after exposure to a heterotopic environment. Hitoshi et al. (2002) have shown that cultured neural stem cells isolated from different regions of the fetal brain maintain a region-specific gene expression profile over many passages and do not adopt a site-specific migration behavior in slice cultures derived from the ganglionic eminence. However, after retrieval from the slice culture and further in vitro propagation, they induce the ventral forebrain marker Dlx2 (Hitoshi et al., 2002). Data from in vivo transplantation experiments in the neonatal and adult brain indicate that heterotopically grafted primary neural precursors fail to adopt site-specific phenotypes (Zigova et al., 1998; Yang et al., 2000; Turner and Shetty, 2003). In contrast, cross-transplantation of cells from or into areas exhibiting postnatal neurogenesis (i.e., hippocampus, olfactory bulb, and cerebellum) has yielded evidence for site-specific differentiation, suggesting that local guidance cues might be maintained in these regions (Renfranz et al., 1991; Vicario-Abejón et al., 1995; Suhonen et al., 1996). Transplantation studies in the embryonic brain have shown that fetal neural progenitors can undergo widespread incorporation and at least partially adopt regional phenotypes (Brüstle et al., 1995; Campbell et al., 1995; Fishell, 1995). Olsson et al. (1997) used ultrasound-guided intrauterine trans- 
plantation to deliver precursor cells into specific regions of the embryonic brain. Their data suggest that the potential for region-specific differentiation primarily depends on the developmental stage of the transplanted cells. Although E10.5 midhindbrain progenitors still have the capacitiy to induce $N k x-2.1$ expression when transplanted into the medial ganglionic emincence, E13.5 progenitors from the same region fail to induce region-specific genes after heterotopic engraftment (Olsson et al., 1997).

Remarkably, an inappropriate regional transcription factor code appears not to preclude migration and incorporation in a heterotopic environment (Olsson et al., 1997; Na et al., 1998). The question arises whether and to what extent a heterotopic positional code impairs function, network integration, and long-term survival of transplanted neurons. Telencephalic progenitors incorporated into the diencephalon and mesencephalon fail to downregulate anterior markers and survive until adulthood ( $\mathrm{Na}$ et al., 1998). In contrast, diencephalic precursors incorporated into cortex appear to die early postnatally (McCarthy et al., 2001). It is tempting to speculate that during development, heterotopic cells are barred from functional integration to protect local circuits from irritating activity.

Our embryonic transplantation paradigm allowed us to address these questions in detail. To our surprise, most incorporated cells did not exhibit regionally appropriate expression of Dlx, Pax6, En1, and Bf1. The lack of acquisition of a local transcription factor code contrasted with the high efficiency of functional integration. All incorporated neurons analyzed displayed characteristic intrinsic membrane excitability and, in all cases in which this property was studied, received synaptic input from host cells. Thus, faulty or lacking expression of positional genes does not appear to preclude functional neuronal maturation or synaptic integration.

Yet, a significant fraction of the transplanted neurons did express regionally appropriate transcription factors. Site-specific differentiation of engrafted neurons is also supported by the detection of regional phenotypes such as glutamatergic pyramidal neurons in cortex and hippocampus or calbindin-positive neurons with morphologies reminiscent of cortical interneurons. In contrast, overall neurotransmitter expression of the engrafted neurons revealed no regional preferences.

The limited extent of regional differentiation might be attributable to several reasons. It is conceivable that only a subpopulation of the transplanted progenitors is susceptible to regionalizing host signals. This would imply that, despite their morphological and immunohistochemical homogeneity (Okabe et al., 1996), ES cell-derived neural precursors represent a rather heterogeneous population. As suggested in the studies by Olsson
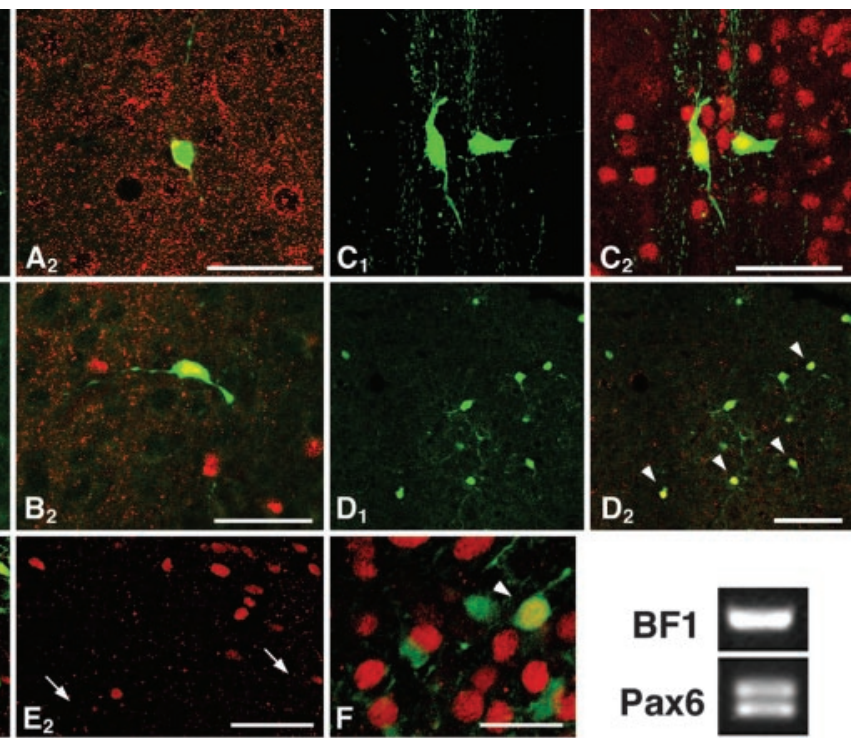

$\mathrm{D}_{2}$
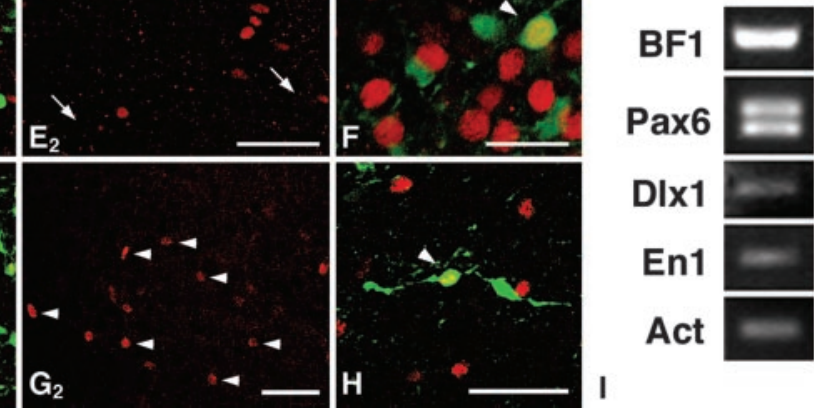

\section{I}

$$
\text { recursors after transplanta- }
$$

Figure 6. Evidence for site-specific and ectopic neuronal differentiation of ES cell-derived neural precursors after transplantaembryonic cerebral ventricles. A, An EGFP-fluorescent cell within the neocortex of a 14-d-old rat brain exhibiting a pyramidal morphology, appropriate orientation of the dendritic tree $\left(A_{7}\right)$, and expression of the neuronal glutamate transporter

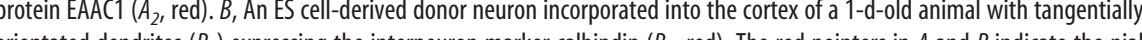
devoid of endogenous Bf1 expression. Arrows indicate Bf1-negative donor cells. F, Only a fraction of the ES cell-derived neurons in indicate some of the double-labeled cells). $H$, En1-positive grafted neuron in the tectum (arrowhead), alongside endogenous confocal plane. Scale bars: $A-C, E, G, H, 50 \mu \mathrm{m} ; D, 100 \mu \mathrm{m} ; F, 25 \mu \mathrm{m}$. I, Expression of region-specific genes in the cultured ES cell-derived neural precursors used for transplantation. Act, $\beta$-actin.

et al. (1997), regional plasticity might be restricted primarily to very immature neural cells at early differentiation stages. It has been hypothesized that heterotopically grafted cells might have to undergo their last division in their new environment to respond appropriately to local cues (Brüstle et al., 1995). Additional studies on differentiating ES cell cultures will be required to define the optimal "window" of susceptibility to extrinsic cues imposing a regional phenotype.

Our data demonstrate that engrafted ES cell-derived neural precursors have the capacity to develop into functional neurons, which integrate synaptically into the host brain circuitry. These findings represent an essential basis for the development of ES cell-based neuronal repair strategies. However, the observation that synaptic integration of ES cell-derived neurons does not depend on the acquisition of a region-specific transcription factor code indicates that functional integration is not strongly regulated by regional signals. This finding should be taken as a note of caution. It argues against a regional "gating" mechanism, which protects local circuits from the integration of nonregionalized, potentially disruptive neurons and strongly emphasizes the need for regional prespecification of the donor cells. 


\section{References}

Auerbach JM, Eiden MV, McKay RD (2000) Transplanted CNS stem cells form functional synapses in vivo. Eur J Neurosci 12:1696-1704.

Bain G, Kitchens D, Yao M, Huettner JE, Gottlieb DI (1995) Embryonic stem cells express neuronal properties in vitro. Dev Biol 168:342-357.

Barresi V, Belluardo N, Sipione S, Mudo G, Cattaneo E, Condorelli DF (2003) Transplantation of prodrug-converting neural progenitor cells for brain tumor therapy. Cancer Gene Ther 10:396-402.

Benninger F, Beck H, Wernig M, Tucker KL, Brüstle O, Scheffler B (2003) Functional integration of embryonic stem cell-derived neurons in hippocampal slice cultures. J Neurosci 23:7075-7083.

Bjorklund A, Lindvall O (2000) Cell replacement therapies for central nervous system disorders. Nat Neurosci 3:537-544.

Brazelton TR, Rossi FM, Keshet GI, Blau HM (2000) From marrow to brain: expression of neuronal phenotypes in adult mice. Science 290:1775-1779.

Brüstle O, Maskos U, McKay RD (1995) Host-guided migration allows targeted introduction of neurons into the embryonic brain. Neuron 15:1275-1285.

Brüstle O, Cunningham M, Tabar V, McKay R (1996) Experimental transplantation in the embryonic, neonatal, and adult mammalian brain. In: Current protocols in neuroscience (Crawley J, Gerfen C, McKay R, Rogawski M, Sibley D, Skolnick P, eds), pp 13.10.11-28. New York: Wiley.

Brüstle O, Spiro AC, Karram K, Choudhary K, Okabe S, McKay RD (1997) In vitro-generated neural precursors participate in mammalian brain development. Proc Natl Acad Sci USA 94:14809-14814.

Brüstle O, Choudhary K, Karram K, Huttner A, Murray K, Dubois-Dalcq M, McKay RD (1998) Chimeric brains generated by intraventricular transplantation of fetal human brain cells into embryonic rats. Nat Biotechnol 16:1040-1044.

Brüstle O, Jones KN, Learish RD, Karram K, Choudhary K, Wiestler OD, Duncan ID, McKay RD (1999) Embryonic stem cell-derived glial precursors: a source of myelinating transplants. Science 285:754-756.

Campbell K, Olsson M, Bjorklund A (1995) Regional incorporation and site-specific differentiation of striatal precursors transplanted to the embryonic forebrain ventricle. Neuron 15:1259-1273.

Carpenter MK, Rosler E, Rao MS (2003) Characterization and differentiation of human embryonic stem cells. Cloning Stem Cells 5:79-88.

Davis CA, Joyner AL (1988) Expression patterns of the homeo boxcontaining genes En-1 and En-2 and the proto-oncogene int-1 diverge during mouse development. Genes Dev 2:1736-1744.

Englund U, Bjorklund A, Wictorin K, Lindvall O, Kokaia M (2002) Grafted neural stem cells develop into functional pyramidal neurons and integrate into host cortical circuitry. Proc Natl Acad Sci USA 99:17089-17094.

Fink JS, Schumacher JM, Ellias SL, Palmer EP, Saint-Hilaire M, Shannon K, Penn R, Starr P, VanHorne C, Kott HS, Dempsey PK, Fischman AJ, Raineri R, Manhart C, Dinsmore J, Isacson O (2000) Porcine xenografts in Parkinson's disease and Huntington's disease patients: preliminary results. Cell Transplant 9:273-278.

Finley MF, Kulkarni N, Huettner JE (1996) Synapse formation and establishment of neuronal polarity by P19 embryonic carcinoma cells and embryonic stem cells. J Neurosci 16:1056-1065.

Fishell G (1995) Striatal precursors adopt cortical identities in response to local cues. Development 121:803-812.

Freed CR, Greene PE, Breeze RE, Tsai WY, DuMouchel W, Kao R, Dillon S, Winfield H, Culver S, Trojanowski JQ, Eidelberg D, Fahn S (2001) Transplantation of embryonic dopamine neurons for severe Parkinson's disease. N Engl J Med 344:710-719.

Fukaya M, Watanabe M (2000) Improved immunohistochemical detection of postsynaptically located PSD-95/SAP90 protein family by protease section pretreatment: a study in the adult mouse brain. J Comp Neurol 426:572-586

Gage FH, Coates PW, Palmer TD, Kuhn HG, Fisher LJ, Suhonen JO, Peterson DA, Suhr ST, Ray J (1995) Survival and differentiation of adult neuronal progenitor cells transplanted to the adult brain. Proc Natl Acad Sci USA 92:11879-11883.

Hatini V, Tao W, Lai E (1994) Expression of winged helix genes, BF-1 and $\mathrm{BF}-2$, define adjacent domains within the developing forebrain and retina. J Neurobiol 25:1293-1309.

Hitoshi S, Tropepe V, Ekker M, van der Kooy D (2002) Neural stem cell lineages are regionally specified, but not committed, within distinct compartments of the developing brain. Development 129:233-244.

Jiang Y, Jahagirdar BN, Reinhardt RL, Schwartz RE, Keene CD, Ortiz-
Gonzalez XR, Reyes M, Lenvik T, Lund T, Blackstad M, Du J, Aldrich S, Lisberg A, Low WC, Largaespada DA, Verfaillie CM (2002) Pluripotency of mesenchymal stem cells derived from adult marrow. Nature 418:41-49.

Johe KK, Hazel TG, Muller T, Dugich-Djordjevic MM, McKay RD (1996) Single factors direct the differentiation of stem cells from the fetal and adult central nervous system. Genes Dev 10:3129-3140.

Kim JH, Auerbach JM, Rodriguez-Gomez JA, Velasco I, Gavin D, Lumelsky $\mathrm{N}$, Lee SH, Nguyen J, Sanchez-Pernaute R, Bankiewicz K, McKay R (2002) Dopamine neurons derived from embryonic stem cells function in an animal model of Parkinson's disease. Nature 418:50-56.

Kuhn HG, Winkler J, Kempermann G, Thal LJ, Gage FH (1997) Epidermal growth factor and fibroblast growth factor-2 have different effects on neural progenitors in the adult rat brain. J Neurosci 17:5820-5829.

Li M, Pevny L, Lovell-Badge R, Smith A (1998) Generation of purified neural precursors from embryonic stem cells by lineage selection. Curr Biol 8:971-974.

Lindvall O (2001) Parkinson disease. Stem cell transplantation. Lancet 358[Suppl]:S48.

Liu JK, Ghattas I, Liu S, Chen S, Rubenstein JL (1997) Dlx genes encode DNA-binding proteins that are expressed in an overlapping and sequential pattern during basal ganglia differentiation. Dev Dyn 210:498-512.

Liu S, Qu Y, Stewart TJ, Howard MJ, Chakrabortty S, Holekamp TF, McDonald JW (2000) Embryonic stem cells differentiate into oligodendrocytes and myelinate in culture and after spinal cord transplantation. Proc Natl Acad Sci USA 97:6126-6131.

Lundberg C, Martinez-Serrano A, Cattaneo E, McKay RD, Bjorklund A (1997) Survival, integration, and differentiation of neural stem cell lines after transplantation to the adult rat striatum. Exp Neurol 145:342-360.

Magavi SS, Leavitt BR, Macklis JD (2000) Induction of neurogenesis in the neocortex of adult mice. Nature 405:951-955.

McCarthy M, Na E, Neyt C, Langston A, Fishell G (2001) Calciumdependent adhesion is necessary for the maintenance of prosomeres. Dev Biol 233:80-94.

McDonald JW, Liu XZ, Qu Y, Liu S, Mickey SK, Turetsky D, Gottlieb DI, Choi DW (1999) Transplanted embryonic stem cells survive, differentiate and promote recovery in injured rat spinal cord. Nat Med 5:1410-1412.

Mezey E, Chandross KJ, Harta G, Maki RA, McKercher SR (2000) Turning blood into brain: cells bearing neuronal antigens generated in vivo from bone marrow. Science 290:1779-1782.

Mezey E, Key S, Vogelsang G, Szalayova I, Lange GD, Crain B (2003) Transplanted bone marrow generates new neurons in human brains. Proc Natl Acad Sci USA 100:1364-1369.

Mujtaba T, Piper DR, Kalyani A, Groves AK, Lucero MT, Rao MS (1999) Lineage-restricted neural precursors can be isolated from both the mouse neural tube and cultured ES cells. Dev Biol 214:113-127.

Na E, McCarthy M, Neyt C, Lai E, Fishell G (1998) Telencephalic progenitors maintain anteroposterior identities cell autonomously. Curr Biol 8:987-990.

Nakatomi H, Kuriu T, Okabe S, Yamamoto S, Hatano O, Kawahara N, Tamura A, Kirino T, Nakafuku M (2002) Regeneration of hippocampal pyramidal neurons after ischemic brain injury by recruitment of endogenous neural progenitors. Cell 110:429-441.

Okabe S, Forsberg-Nilsson K, Spiro AC, Segal M, McKay RD (1996) Development of neuronal precursor cells and functional postmitotic neurons from embryonic stem cells in vitro. Mech Dev 59:89-102.

Olsson M, Campbell K, Turnbull DH (1997) Specification of mouse telencephalic and mid-hindbrain progenitors following heterotopic ultrasoundguided embryonic transplantation. Neuron 19:761-772.

Ostenfeld T, Caldwell MA, Prowse KR, Linskens MH, Jauniaux E, Svendsen CN (2000) Human neural precursor cells express low levels of telomerase in vitro and show diminishing cell proliferation with extensive axonal outgrowth following transplantation. Exp Neurol 164:215-226.

Panganiban G, Sebring A, Nagy L, Carroll S (1995) The development of crustacean limbs and the evolution of arthropods. Science 270:1363-1366.

Price M, Lemaistre M, Pischetola M, Di Lauro R, Duboule D (1991) A mouse gene related to Distal-less shows a restricted expression in the developing forebrain. Nature 351:748-751.

Renfranz PJ, Cunningham MG, McKay RD (1991) Region-specific differentiation of the hippocampal stem cell line HiB5 upon implantation into the developing mammalian brain. Cell 66:713-729.

Reubinoff BE, Itsykson P, Turetsky T, Pera MF, Reinhartz E, Itzik A, Ben-Hur 
T (2001) Neural progenitors from human embryonic stem cells. Nat Biotechnol 19:1134-1140.

Reynolds BA, Weiss S (1992) Generation of neurons and astrocytes from isolated cells of the adult mammalian central nervous system. Science 255:1707-1710.

Rossi F, Cattaneo E (2002) Opinion: neural stem cell therapy for neurological diseases: dreams and reality. Nat Rev Neurosci 3:401-409.

Shihabuddin LS, Hertz JA, Holets VR, Whittemore SR (1995) The adult CNS retains the potential to direct region-specific differentiation of a transplanted neuronal precursor cell line. J Neurosci 15:6666-6678.

Snyder EY, Taylor RM, Wolfe JH (1995) Neural progenitor cell engraftment corrects lysosomal storage throughout the MPS VII mouse brain. Nature 374:367-370.

Stoykova A, Gruss P (1994) Roles of Pax-genes in developing and adult brain as suggested by expression patterns. J Neurosci 14:1395-1412.

Strübing C, Ahnert-Hilger G, Shan J, Wiedenmann B, Hescheler J, Wobus AM (1995) Differentiation of pluripotent embryonic stem cells into the neuronal lineage in vitro gives rise to mature inhibitory and excitatory neurons. Mech Dev 53:275-287.

Strübing C, Rohwedel J, Ahnert-Hilger G, Wiedenmann B, Hescheler J, Wobus AM (1997) Development of G protein-mediated Ca2 + channel regulation in mouse embryonic stem cell-derived neurons. Eur J Neurosci 9:824-832.

Studer L, Tabar V, McKay RD (1998) Transplantation of expanded mesencephalic precursors leads to recovery in parkinsonian rats. Nat Neurosci 1:290-295.

Suhonen JO, Peterson DA, Ray J, Gage FH (1996) Differentiation of adult hippocampus-derived progenitors into olfactory neurons in vivo. Nature 383:624-627.
Svendsen CN, Smith AG (1999) New prospects for human stem-cell therapy in the nervous system. Trends Neurosci 22:357-364.

Tao W, Lai E (1992) Telencephalon-restricted expression of BF-1, a new member of the HNF-3/fork head gene family, in the developing rat brain. Neuron 8:957-966.

Tucker KL, Meyer M, Barde YA (2001) Neurotrophins are required for nerve growth during development. Nat Neurosci 4:29-37.

Turner DA, Shetty AK (2003) Clinical prospects for neural grafting therapy for hippocampal lesions and epilepsy. Neurosurgery 52:632-634.

Vicario-Abejón C, Cunningham MG, McKay RD (1995) Cerebellar precursors transplanted to the neonatal dentate gyrus express features characteristic of hippocampal neurons. J Neurosci 15:6351-6363.

Walther C, Gruss P (1991) Pax-6, a murine paired box gene, is expressed in the developing CNS. Development 113:1435-1449.

Wernig M, Tucker KL, Gornik V, Schneiders A, Buschwald R, Wiestler OD, Barde YA, Brüstle O (2002) Tau EGFP embryonic stem cells: an efficient tool for neuronal lineage selection and transplantation. J Neurosci Res 69:918-924.

Yang H, Mujtaba T, Venkatraman G, Wu YY, Rao MS, Luskin MB (2000) Region-specific differentiation of neural tube-derived neuronal restricted progenitor cells after heterotopic transplantation. Proc Natl Acad Sci USA 97:13366-13371.

Zhang SC, Wernig M, Duncan ID, Brüstle O, Thomson JA (2001) In vitro differentiation of transplantable neural precursors from human embryonic stem cells. Nat Biotechnol 19:1129-1133.

Zigova T, Pencea V, Betarbet R, Wiegand SJ, Alexander C, Bakay RA, Luskin MB (1998) Neuronal progenitor cells of the neonatal subventricular zone differentiate and disperse following transplantation into the adult rat striatum. Cell Transplant 7:137-156. 